\title{
The Motif of the Angel(s) of Death in Islamic Foundational Sources
}

\author{
BOŻENA PROCHWICZ-STUDNICKA \\ Jesuit University lgnatianum in Cracow, Poland \\ bozena.prochwicz-studnicka@ignatianum.edu.pl, ORCID: 0000-0002-1644-252X
}

\begin{abstract}
The article aims at presenting the motif of the angel(s) of death in the foundational texts of Islam, i.e. the Quran, and in the sunna of the Prophet Muhammad. The scope of the research was limited to the dynamic motifs and therefore involves only the angels who participate in events associated with the time in which a person dies. The first part of the present study provides an overview of the foundational sources of Islam and the second consists of an analysis of the eponymous theme which is featured in them. At the end, an attempt has been made to draw conclusions as far as the conceptual and imagery dimensions of the motif are concerned.
\end{abstract}

Keywords: angels, death, soul, Quran, sunna of the Prophet Muhammad

The three great monotheistic religions share the belief in angels. The present article refers to one of the angelological motifs ${ }^{1}$ featured in a group of texts which represent Islamic religious tradition. The field of research includes the angel(s) of death but it was limited to the dynamic motifs and therefore it involves only the angels who participate in events associated with the time in which a person dies (static motifs which refer to the elements of appearance, attributes, names, the position in the hierarchy of the angelic world etc. were omitted). Thus, the expression "angel(s) of death" should be understood as the angel(s) involved in immediately at-, upon- and after-death happenings. The article consists of an introduction to the foundational sources of Islam with an exposition of the criteria of the selection of the source corpus and an analysis of the eponymous theme which is featured in it. The short introduction to the belief in angels in Islam precedes the analysis.

1 In the text the term "motif" is interchangeably used with the term "theme." 


\section{Islamic Foundational Sources}

The Muslim doctrine unfolded from two sets of texts, the Quran ${ }^{2}$ and the sunna of the Prophet Muhammad. For the Muslims, the Quran is the Word of God revealed to the Prophet over the period of more than 20 years through the Archangel Gabriel. The final version of the Quran (i.e. its uniform consonantal skeleton - rasm) was established in 650, some 20 years after Muhammad died. This conventional dating of the Quranic text or at least a very considerable portion of it is supported by some researches partially on the basis of the results of radiocarbon dating method. ${ }^{3}$ Some other adduce an evidence in support of the hypothesis on a late seventh-century closure of the rasm. ${ }^{4}$ In any case, unlike in the Bible, where the body of texts was created over many generations, a similar pattern of ideas forming and maturing can hardly be found in the Quran.

Based on the historical contexts of certain Quranic verses, Muslims scholars classified the individual suras into Meccan and Medinan, depending on whether they were revealed to the Prophet while he was in the city of Mecca (610-622) or in the city of Medina (622-632). ${ }^{5}$ Oriental studies showed, however, that contrary to the clear-cut division supported by the Islamic scholars, there are suras that contain passages dating from both periods. ${ }^{6}$ Apart from doctrinal beliefs and legal or ethic guidance, the Quran contains numerous references to Jewish, Christian and pre-Islamic traditions.

The Quran emerged in closed form and as such could not satisfy the legal and theological needs of the growing Islamic community. Especially legal practice required a number of solutions that would have been underpinned by Muhammad's unchallengeable authority. The revelation was thus extended to include his words and actions related to specific situations. In time, the reports (hadiths) so compiled formed the sunna of the Prophet or tradition of the Prophet Muhammad, a collection of texts which not only implemented the rules of the Quran but also grew to be a source of dogmas and laws.

2 In this article the ALA-LC transcription is used, with the exception of those Arabic terms, which are long rooted in the English language and/or widely recognized in the scholarly discourse (then the simplified transcription rules are applied).

3 See e.g. Sinai, The Quran, 45-47, who points out the radiocarbon dating of the Quranic manuscript fragments kept inter alia at the Tübingen University Library and the Berlin State Library.

4 See e.g. von Bothmer - Ohlig - Puin, "Neue Wege," 33-46; Sadeghi - Bergmann, "The Codex," 343-436; Sadeghi - Goudarzi, "Șanā' I," 1-129. Additionally, on the basis of the research in the parchment manuscripts of the Quran found in the Grand Mosque in Sana in the 1970s, as well as in the few monuments of writing (receipts, coins, inscriptions) a hypothesis that shifted the time of the fixing of the final version of the Quran to the 9th century was formulated.

5 The suras are arranged in the Quran according to their length, from longest to shortest.

6 Trail-blazing research in the area was carried out in the West by Theodor Nöldeke, who additionally classified the Meccan suras into three groups corresponding to three phases of Muhammad's activity. The following editions of his work were expanded, see Nöldeke et al., The History of the Qur'àn. 
Although some of the Prophet's companions and successors made individual notes of the reports to serve as mnemonic aids, putting traditions into writing was unsystematic action since the hadiths were originally intended to be passed on orally. ${ }^{7}$ Over the course of time untrue or fabricated traditions began to pop up among true ones and the number of them was growing. One of the key methods of authenticating the hadiths involved establishing the reliability of the transmitters (biographical evaluation) and analysing the chain of transmitters; the content of the accounts would also be analysed. Consequently, the hadiths were classified with respect to the degree of single transmitter reliability, the method of reception of the hadith and the number of witnesses, as well as the continuity (completeness) of the chain of transmitters. In the 9th century, systematic studies of the hadiths were finally conducted, giving them ordered and conventionalised form. Of the traditions existing in the Muslim world (Sunni Islam), the six absolutely authoritative hadith collections (al-kutub as-sitta) were ranked highest. Apart from these most normative collections, individual schools of Islamic law as well as theological schools hold their "own" huge collections of hadith. ${ }^{8}$

Besides the Quran, it is the tradition of the Prophet that tracks the early ideas (i.e. those dating back to before the 9th century) that touch upon the overall socio-religious life, including dogmatic issues. The remarkable number of hadiths, which run in tens of thousands compiled in hundreds of collections, hinders full exploitation of them. As the objective of this paper is to present the angel(s) of death motif as an element of cultural diffusion, analysis of the entire sunna of the Prophet is not necessarily required. In this article hadiths are sourced from the canonical collections (al-kutub as-sitta) of Al-Buhārī (d. 870), Muslim (d. 875), Ibn Māğa (d. 886), At-Tirmidīi (d. 892), as well as from the Musnad of Ahmad Ibn Hanbal (d. 855), classical Sunni commentaries to the Quran (tafsìr, pl. tafäsìr) and classical eschatological textbooks (Al-Qurțubī, Al-Muhtașar aș-șaḥīh, Ibn Qayyim al-Ğawziyya, Kitāb ar-rūh h) serving didactic and homiletic purposes, which contain an ordered compilation of traditions relating to death, the end time and the Last Judgement, including faith in angels.

Whether or not the typology established by Muslim scholars recognised the authenticity of the traditions, ${ }^{9}$ the hadiths reflect the cultural realities of the burgeoning Islamic world and as such are treated as the backbone of the Arab-Muslim cultural code. Analysis of hadiths can help reconstruct the meanings assigned to things

Schoeler, "Recording," 93, passim.

Kościelniak, Tradycja, 30-32; Schoeler, "Recording," 93-99.

The majority of Western researchers are of the opinion that the sunna partly contains non-authentic material, the reason being poor methodological instruments adopted by the Muslim scholars to verify the genuineness of the hadiths. For more on the topic see Brown, "Western," 39-56; Kościelniak, Tradycja, 106-118. 
and events in the first centuries of Islam, and trace back the world vision of the day, including eschatological perceptions and beliefs. As Sylvia Akar ${ }^{10}$ puts it:

Remembering is a process of collective selection, though it is individuals, of course, as group members who remember. In the same way, the principles of accepted behaviour found in the hadith reports have become an agreed code of conduct and code of good and bad, regardless of the thoughts that Muslims may have on the authenticity of the reports. [...] Every piece of information we have is an answer to a need, be it a real need or an imaginary one. There has been a need to know the Prophet's opinion on a certain matter or there has been a need for passing on information of his supposed opinion on a matter, otherwise there would have been no sense in transmitting the information. An answer always presupposes a question, a text is an answer to a need in the community.

\section{Angels in Islam}

The existence of angels (Arabic maläika) ${ }^{11}$ is one of the principal religious truths in Islam, and belief in them is prescribed in the Quran. Although the Quran mentions them often (about 90 times) ${ }^{12}$, not many are known by their names, except for Gabriel (Arabic Ğibrīl), Michael (Arabic Mīkāl), Mālik, Hārūt and Mārūt. Angels are more often portrayed in the Quran through specific functions, for example mu'aqqibät guardian angels ${ }^{13}$ (13:11), hafaza - recorders (6:61), tāliyāt [dhikran] - those who recite [God's word] (37:3), sāiq wa-shahìd - an [angel] to drive [each person] on and to bear witness (50:21).

Angels are immaterial beings, created of light, able to assume a variety of shapes visible to men (only the prophets could see them in their luminescent form). Angels are absolutely obedient to God. Islamic angelology has worked out a detailed typology of angels with respect to their functions, some of them have been named. ${ }^{14}$ Angels are God's messengers in the first place: Muhammad received his revelations through the Archangel Gabriel. God charges angels also with other responsibilities relating to human life in its earthly and eschatological dimensions. Angels not only assist people in difficulties but also incessantly records their good and evil doings. At the end of time, angels will lead men to the Last Judgement, and keep guard of human memory and do the weighing of souls. There are also angels whose services are related to

\footnotetext{
10 Akar, "No, Said the Prophet," 95-96.

11 The Arabic malak (pl. malä'ika) could have its source in the Ethiopian mal'äk (pl. maläeket) - messenger, most likely borrowed from Aramaic or Hebrew, Macdonald, "Malāika," 216.

12 Kościelniak, Tematyczna konkordancja, s.v. aniołowie, Gabriel, Michał, Malik, Harut, Marut.

13 If not indicated otherwise, all translations of passages from the Quran are after Haleem, The Qur'an.

14 Attempts to interpret systematically angelological issues are found in mature theological discussions; see Wensinck, The Muslim Creed, 198-202.
} 
human death. Furthermore, God's court is formed of hosts of angels - they are close to him, carry his throne, proclaim his glory and extoll him everlastingly. They protect the walls of heaven from the eaves-dropping jinns and demons. The guardian of hell is an angel, so is that who watches the gate of paradise. ${ }^{15}$

The robust development of the angelological tradition might have stemmed from the fact that God in Islam totally transcends human experience and cognition, which prevents any interaction between His world and the earthly world. ${ }^{16}$ The angels are like a metaphorical bridge that links heaven and earth. Peter Lamborn Wilson said "virtually nothing can occur without the intervention of the Angels. Mohammed said that every raindrop that falls is accompanied by an Angel - for even a raindrop is a manifestation of being. The Angelic World is a place inhabited by living creatures but more than that, it constitutes the very relationship between the world and God." ${ }^{17}$

\section{Angels of Death in the Light of Islamic Foundational Sources}

\subsection{Defeating the Enemies in the Battlefield}

The relationship between angels and death is traceable in the context of the work of destruction. The theme appears in the Medinan period of the Prophet Muhammad's activity. The emigration (hijra) from Mecca to Medina in 622 put Muhammad symbolically on a new path of his mission: one of leadership (in addition to his previous mission of a prophet). Muhammad became a reformer, community organiser, politician, and military leader. The Islamic community (umma) in Medina matured and expanded in the shadows of military skirmishes and combats, which explains why the suras of the period contain many references of political and military character.

With the agency of angels God helped Muhammad score a victory at Badr (624). It was the first battle fought between the followers of Muhammad and the Qurayshites of Mecca. According to the revelation, the angels' interference helped the faithful not only to counterbalance but also to outnumber the enemy forces: "When you begged your Lord for help, He answered you, «I will reinforce you with a thousand angels in succession»." (8:9, see also 8:12; 3:124-125). The tradition developed this image: it was Gabriel who arranged the ranks of the angels and took the lead of them ${ }^{18}$; the angels

15 Discussed more broadly in contemporary Arabic studies of angels such as Umar Sulayman 'Abd Allāh al-Ashqar, 'Ālam al-malāika al-abrär; Mușțafā Āshūr, 'Ālam al-malāika: asräruhu wa-hnafāyāhu.

16 For example, the Quran 6:103; 42:51. Cf. John Paul II, Crossing the Threshold, 92: "Some of the most beautiful names in the human language are given to the God of the Quran, but He is ultimately a God outside of the world, a God who is only Majesty, never Emmanuel, God-with-us."

17 Wilson, Angels, 38.

18 Șahịh al-Buhārī, V, 198-199 (hadith 3992), 199-200 (hadith 3395); Musnad al-Imām Aḥmad Ibn Hanbal, I, 572 (hadith 1257); see also Wensinck, A Handbook, $29,234$. 
rode horses whose hoofs never touched the ground. In line with the custom, they were decked out like troopers and wore turbans in white and yellow. ${ }^{19}$ Since the Quran mentions also three thousand soldiers, according to the hadiths God sent then two more thousands, led by Michael and Israfil. The fighters at Badr allegedly witnessed inexplicable events: they could hear whips swooshing, and if they turned back they would see the opponent lying dead with a whip mark on his face. ${ }^{20}$ The angels appeared mostly in human form but they were not immediately recognized as angels.

The Quran mentions invisible forces ( $\breve{g} u n \bar{u} d)$ twice. ${ }^{21}$ Although the word "angels" does not come up, the context identifies those forces as "the ranks of angels."22 The first time occurred during the Battle of the Ditch (627): "You who believe, remember God's goodness to you when mighty armies massed against you: We sent a violent wind and invisible forces against them" (33:9). During the defense of Medina, tactics unknown on the Arabian Peninsula until then were used to dig a moat as a line of defense against raiders into the city. The ditch made armed combat impossible, yet since the word was a weapon as legitimate as the sword in pre-Islamic oral culture, within a couple of weeks the fighters were exchanging insults in verse or prose standing on either side of the ditch. Finally, God stirred up a violent sand storm and his invisible helpers laced up the enemy's tents, leaving them for the elements.

The other reference is one to the battle of Hunayn (630), when the enemy made a surprise attack on Muhammad's followers marching through the mountains, which caused chaos and made the troops disperse. On battlefield, God helped Muhammad and the soldiers who stayed behind with him: "Then God sent His calm down to His Messenger and the believers, and He sent down invisible forces. He punished the disbelievers - this is what the disbelievers deserve" (9:26).

In all the three examples above, it is God of the army who pushed to the fore to defeat Muhammad's opponents (i.e. those who do not want to believe in one God and the Prophet's mission) and angels in countless and nameless ranks are a weapon in his hands.

\subsection{Seizing the Soul and Ascending with It Into Heaven}

In Islamic foundational sources, the theme of angels as ranks fighting in armed combat runs parallel to the motif of angels "at man's death." In the Quran, the latter is found in suras of both the Meccan (dating from the late Meccan period), and Medi-

\footnotetext{
Al-Maḥallī - As-Suyūțī, Tafsìr al-ğalälayn, I, 249-250; Nasr et al., The Study Quran, 360, 902-903. Al-Qurțubī, Al-Muhtașar aṣ-șahịh, 57.

Sing. ğund - an army, a military force, a body of troops or soldiers, auxiliaries, but also any kind or species of created things or creatures, regarded as alone, apart from others, Ibn Manzūur, Lisān al-'Arab, s.v.; Lane, An Arabic-English, s.v.

22 Nasr et al., The Study Quran, 948, 1816.
} 
nan periods. The link between the angels and the human departure from this world comes through in the verb tawaffä: "If only you [i.e. the Prophet Muhammad] could see, when the angels take the souls of the disbelievers..." (8:50, see also 4:97, 6:61-62, $7: 37,16: 32,47: 27)$. The stem $w-f-y$ carries the concept of fulfilment or accomplishment. Angels take away the soul of a man whose span of life has been fulfilled. As God holds authority over human life, it is Him who sets the moment of birth and death for each man: "God takes the souls of the dead" (39:42). There were attempts to reconcile the use of the same verb in the context of the actions of God and the angels by pointing up the instrumental function of the latter: God causes someone to die, because his or her foreordained term of life has been fulfilled but the very process of seizing the souls belongs to the duties of the angels. ${ }^{23}$

In the Quran the way angels seize the human soul is not described in much detail. Neither do they have names. With one exception, we are dealing with an undiversified mass of angels (al-maläika) or (God's) messengers (rusul [Alläh]). Muhammad grew up in a collectivistic environment and in order to spread a new religious idea he retained the model of an individual merged with the group, hence the Quran uses basically impersonal forms to address men, which underscores their homogeneity, ${ }^{24}$ yet it applies the same formula to the angels.

A historical context looms very clear in two verses: the disbelievers (8:50) and those who hate what God has sent down (47:26) will have their faces and backs struck to taste the punishment of the Fire. The corporeal nature of post-mortal experiences is a characteristic feature that prevails in the Quranic imagery.

The same duty was assigned to one of the angels. Sura 32:11, another late Meccan sura (though probably not established until in Medina), refers overtly to the Angel of Death (malak al-mawt), dubbed 'Izrāill in tradition and, subsequently, in Islamic angelology (the figure is known in Jewish tradition as Azrael). It is hard to determine conclusively the relationship between the angels discussed above and the Angel of Death based on the Quranic verse. His role is the same: "Say, «The Angel of Death put in charge of you (wukkilka bi-kum) will reclaim you, and then you will be brought back to your Lord.»" It is only the hadiths that split the responsibilities by bringing the angels to the eschatological arena.

The Quranic verse puts it clearly that the angel has a permanent function and that the function has been vested in him by God. The tradition of the Prophet refers still more unequivocally to the task assigned to the Angel of Death: wukkilka bi-kum (put in charge of you) $\rightarrow$ bi-qabdikum (of seizing you) $\rightarrow$ bi-qabd arwāhikum

23 Al-Qurțubī, Al-Ğamī‘ XVII, 19, XVIII, 286-287; Nasr et al., The Study Quran, 1999. Cf. tawaffähu Alläh - God brought to the end one's mundane life span and took him to Himself; thus, passive (tuwuffi$y \bar{a}-$ to die) means: to be brought by God to the end (about one's life span), to finish one's fixed term of life in this world, Ibn Manz̄ūr, Lisān al-'Arab, s.v.; Lane, Arabic-English Lexicon, s.v.; also O'Shaughness, Muhammad's Thoughts, 59.

24 See e.g. 2:104, 172, 178, 183, 254, 264; 5:1, 2, 6, 35, 54, 57, 87, 90, 94, 95; 9: 28, 34, 119, 123. 
(of seizing your souls). ${ }^{25}$ This responsibility has been laid on him from the beginning of creation. ${ }^{26}$

Parenthetically, the Quran, tradition and, later, even the Islam doctrine use two Arabic terms to describe that element of human nature that is separated from man at death and is colloquially called the soul - rüh and nafs. Nafs (Hebr. nefeš) means soul but also breath, sometimes human being or living creature. Nafs (soul) is generally an element exposed to temptations and where intelligence and judgement are located. $R \bar{u} h$ (Hebr. $r \bar{u} a h)$, in turn, is spirit, the vital principle or animating force or soul. In the context of death, in the Quran, 39:42, "God takes the souls (nafs, pl. anfus) of the dead and the souls of the living while they sleep - He keeps hold of those whose death He has ordained and sends the others back until their appointed time..." In one of the traditions of the Prophet Muhammad, the word anfus was replaced with arwāh in a formula identical to the verse above. In Quran-related literature the former was sometimes used to refer to that part of the human nature that the angel seized at death; sometimes it was believed that an angel seizes the rüh, which is instilled in a person at birth and which will be returned at the end of days so that the person can be resurrected; the nafs, conversely, remains with the body. ${ }^{27}$

Back to the subject, the sunna of the Prophet Muhammad gives a precise stepby-step description of how the soul is divorced from the body. Death in the Quran and in the traditions appears as a difficult and painful experience, particularly for disbelievers (kuffär). The soul is pulled out of the body through the throat (56:83). An angel takes a position at the head of the dying person and extracts it differently depending on the soul. If the decedent is a believer (mu'min), ${ }^{28}$ the angel speaks to him gently, his gestures are delicate, he asks the soul to come out and it "emerges like a drop of water flows from a water-skin." The Angel of Death is accompanied by a group of angels which the sunna interprets as 'Izräill's helpers. They are brightfaced and the tradition alternatively calls them maläikat ar-rahma, the angels of mercy. Within a split second they grab the soul, and, wrapped in a perfumed shroud redolent of paradise, it travels with them through seven heavens. It is unclear (and even doubtful) whether the soul is put before God and whether God addresses it directly. Reports vary on this issue, ${ }^{29}$ in the majority of them God de-

25 Sunan Ibn Māğa, IV, 55 (hadith 2778); Al-Qurțubī, Al-Ğamī', XVII, 21, XVIII, 286; Al-Muhallī - AsSuyūtịi, Tafsìr al-ğalälayn, III, 48.

26 Al-Qurțubī, Al-Ğamī', XVII, 22.

27 Gaudefroy-Demombynes, Narodziny islamu, 244-248, 315; see also Smith - Haddad, Islamic Understanding, 36. The author of this paper consistently uses the word "soul" regardless of the terminology used in the Arabic original.

28 This term appears in most traditions. However, in some of them the criterium of distinction are deeds of a man - șāliḥ (good, righteous) vs sayyi' (bad, evil, also: unrighteous, sinful), Ibn Manz̄ūr, Lisān al-'Arab, s.v.; Lane, Arabic-English Lexicon, s.v.

29 God addresses the soul directly in the report quoted by Ibn Qayyim al-Ğawziyya, Kitāb ar-rūh, I, 134. In a report quoted by Al-Qurțubi, Al-Muhtașar aș-șahịh, 57, similarly God, having talked to the soul, orders 
clares the temporary fate of the soul and instructs the angels to take the soul back to the earth:

The angels ascend with it. Whenever they pass by [various] kinds of creatures between the earth and the sky, they ask: "Whose soul is this?" [The angels] answer: "This is a soul of so-and-so calling it with the nicest of its names." When they reach the gates of the worldly sky, they open for it. In every sky [they pass], its most privileged inhabitants bid the soul farewell as it reaches the seventh sky. Then, it is said: "Write down its record in 'Illiyyin." What will explain to you what 'Illiyyin is? - a clearly written list, witnessed by those brought near. ${ }^{30}$ So, its record is written down in 'Illiyyin. Then, it is said: "Take it back to the earth, since I promised them [i.e. humankind] that as I created them from the earth, so I will bring them back to it, and then bring them out at other times." ... So, the soul is returned to the earth and put back to its body. ${ }^{31}$

The way the Angel of Death speaks to a disbeliever (käfir) is harsh and severe, his soul "is dragged out like a skewer is pulled out of wet wool," and wrapped in a sackcloth. Black-faced angels are already waiting nearby, referred to as maläikat $a l-{ }^{\prime} a d \bar{a} b$ - the angels of punishment; they take the soul but the door to heaven does not open for it. This soul, too, follows the way back to the grave. ${ }^{32}$

\subsection{Questioning in the Tomb}

Though not directly, the Quran suggests several times the existence of punishment in the tomb (e.g. 6:93, 9:101, 32:21, 40:11, 52:47) without, however, placing an angel figure in this context. Tradition, in turn, saw the development of the concept of punishment in the tomb (' $a \underline{a} \bar{a} b a l-q a b r)$. There are many reports on this matter. They give an impression as if the tradition of the Prophet wanted to interpret a requirement of expiation embracing everyone in a more positive way. There are hadiths in which the punishment is restricted only to unbelievers (or unrighteous). As far as the believer (or righteous) is concerned, an experience of the pressure (daght) of the tomb is imposed on him or her, however it looks „like the compassionate mother whose son complains to her of a headache and she strokes his head gently." ${ }^{33}$ Ulti-

the angels to show it the pleasures that await it in heaven.

30 The Quran 83:19-21. 'Illiy un - there is a disagreement as for the meaning of this word. According to some exegetes they are high places, a name of the upper part of the heavens, where the register of men's good actions is preserved, some point to the register itself. It is unquestionably derived from the Hebrew 'elyon (the highest), Penrice, A Dictionary, 100.

31 Musnad Abī Dāwūd aț-Ṭayālisī, in: Al-Qurțubī, Al-Muhtașar aṣ-șahịhh, 73 (own translation).

32 Many variants (of slight difference) of the tradition in e.g.: Sunan Ibn Mäğa, V, 371-372 (hadith 4262); Ibn Qayyim al-Ğawziyya, Kitāb ar-rūh, I, 115-118, 134; Al-Qurțubī, Al-Muḥtașar aṣ-șahịh, 73-74, 76-77; see also Wensinck, A Handbook, 22, 53.

33 Ibn Qayyim al-Ğawziyya, Kitāb ar-rūḥ, I, 162; Smith - Haddad, Islamic Understanding, 46. 
mately, there is a kind of recompense in the tomb granted to the faithful and just. It seems that along with such an interpretation there appeared an idea of the interrogation with an associated presence of two angels which, right after the burial, come to the deceased person's grave, tell them to sit up and interrogate them to test their faith. Despite small variances, tradition shows that the questions asked of the soul concern God, religion and the Prophet Muhammad. Correct answers given, the angels open a window or the door of the grave for the soul to be able to look at heaven and feel the fragrance coming down from there. ${ }^{34}$ Otherwise,

when the dead man is a hypocrite or an unbeliever and, with respect to the Prophet he is asked about his opinion about that man, he will say: "I do not know, I used to repeat what other people said." Then it is said to him: "You will never know or understand." Thereupon he is given a beating with iron rods, so that he emits a shout for every creature beside man and jinn to hear. ${ }^{35}$

In the canonic collections of hadiths the angels are called by their names just once: Nakīr and Munkar. ${ }^{36}$ Sometimes, the questioning (or trial) is done by a single angel, sometimes no one is mentioned. ${ }^{37}$

Analysis of the motif of the angel(s) of death in the Quran and the sunna of the Prophet Muhammad from a textual perspective may foster several conclusions. Firstly, the Quran contains key eschatological ideas that suggest the presence of angels at and right after the death of a human, yet basing solely on the Quranic messages, their function and the way they perform these are hard to define precisely. It is virtually impossible to establish the sequence of events from the moment a person dies attended by the angels. Although the Quran uses a highly pictographic style in its descriptions of heaven and hell, the passages under discussion, while dynamic and at times vivid, are fragmentary and allusive. It was only the literature of the prophetic tradition that refined the Quranic ideas.

At the same time the collections of hadiths contain narratives of various periods of origin and are extremely difficult to date. To establish their chronology, western

34 Islamic foundational sources do not say much about the state between death and resurrection and Doomsday, yet the dead person, after interrogated by the angels, goes undoubtedly through an experience that anticipates his or her eternal destiny. Tradition has expanded chiefly the imagery of punishment of the tomb, Wensinck, A Handbook, 89. For more on the same subject see Smith - Haddad, The Islamic Understanding, 41-48, Macdonald, "The Twilight," 77.

35 Juynboll, Encyclopedia, 459. Many variants (of slight difference) of the tradition in: e.g. Sahīh al-Buhārī, II, 242-243 (hadith 1338), 262-263 (1374); Sahịh Muslim, VII, 262, 264 (hadith 7216, 7221); Al-Qurțubi, Al-Muhtașar aș-șahīh 74, 79; Ibn Qayyim al-Ğawziyya, Kitāb ar-rūh, I, 135-136, 158, 256.

36 Ğamī' at-Tirmidīi, II, 443-444 (hadith 1071).

37 Sahịh al-Buhārī, II, 41-42, 261 (hadith 922, 1369); Wensinck, The Muslim Creed, 164, n. 5. 
research applies a range of consolidated methods based, not without reservations, on classical text-critical techniques. ${ }^{38}$ One of the considerations is the level of fictionalisation (introduction of literary and rhetorical embellishment). Pavel Pavlovitch explains that the process "may involve minor changes, such as using specific connectives to increase narrative cohesion, along with considerable revisions, such as introducing new motifs and actors, specifying the historical circumstances of a particular event, or even inventing characters and events." ${ }^{39}$ The hadiths expanded or even transformed the content, which autotomized eschatological descriptions and narratives. ${ }^{40}$ For example, the motif of tomb trial conducted by Munkar and Nakir could have unfolded along this course: ${ }^{41}$

- the idea of after-death punishment

Quran: humiliating punishment of the wicked in their death agonies (6:93); tasting a nearer torment prior to the greater torment (32:21); another punishment awaiting the evildoers (52:47)

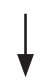

- the punishment in the tomb ( $a \underline{d} a \bar{a} b$ al-qabr)

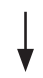

- the interrogation in the tomb (su'a $\bar{l})$ prior to the punishment in the tomb

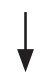

- the interrogation by one angel prior to the punishment in the tomb

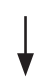

- the interrogation by two angels prior to the punishment in the tomb

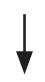

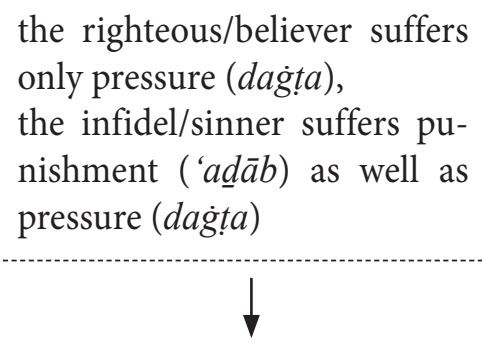

the righteous/believer enjoys various pleasures (e.g. a window to paradise appears, the tomb is enlarged and filled with light)

- the interrogation by two angels: Munkar and Nakīr prior to the punishment in the tomb

\footnotetext{
38 Pavlovitch, "Dating," 121-124.

39 Pavlovitch, "Dating," 122.

40 Cf. Günther, "The Poetics," 190.

41 Own elaboration of the scheme showing the presumable elaboration of the concept of the examination and the punishment of the dead in their tombs by Munkar and Nakir based on Wensinck, The Muslim Creed, 164-165; Macdonald, "The Twilight," 57-58.
} 
Secondly, the anthropomorphisation of the eschatology of death-related events is a distinctive feature of both the Quranic message and the tradition of the Prophet. With that imagery, scenes and events become palpable, vibrant and, by that, evocative in a way that appeals not just to the mind but also to emotions ${ }^{42}$. God's actions undergo anthropomorphisation too, when he sends the army of "a thousand angels in succession," "five thousand swooping angels" etc., does the work of destruction and conquers the enemy.

Thirdly, the angels (except for the Angel of Death) appear in the Quran as undifferentiated groups responsible for particular tasks in relation to people, who also form a collective. Tradition cultivates this concept, though it introduces interrogating angels and some accounts have the form of narratives relating to specific individuals, such as participants of events of the Medinan umma. The purpose of such individualised eschatology seems to be to highlight the inescapable eschatological events in every man's life, to reassure Muslim believers and to call upon non-Muslims to convert to Islam.

Finally, it is generally assumed that some elements of angelological traditions of two earlier monotheisms can be identified at both conceptual and imagery levels of the Islamic foundational sources. To trace the presence of the motif in textual sources of Judaism and early Christianity and to examine the level of its convergence would lay the foundations for the question about the possible passage of the theme to Islamic ground by way of borrowing. This issue could become the central problem to be researched by another study.

\section{Bibliography}

\section{Primary sources}

Ğāmi at-Tirmid̄ī / English Translation of Jāmi 'At-Tirmidhī. Arabic-English (ed. Hāfiz Abu Tāhir Zubair 'Ali Za'i; trans. Abu Khaliyl) (Riyadh - Jeddah: Maktaba Dar-us-Salam 2007) II.

Al-Ğawziyya, Ibn Qayyim, Kitāb ar-rūḥ (ed. Muḥammad Ağmal Ayyūb al-Iṣlāhī) (Makka: Dār 'Ālam al-Fawäid [s.a.]) I.

Haleem, A.M.A.S. (ed. and trans.), The Quran. A New Translation (Oxford: Oxford University Press 2004).

Al-Mahallī Ğalāl ad-Dīn, As-Suyūṭị Ğalāl ad-Dīn, Tafsīr al-ğalālayn (Karachi: Maktabat alBušrā 1431 AH/2010) I, III.

Musnad al-Imām Ahmad Ibn Hanbal / English Translation of Musnad Imam Ahmad bin Hanbal. Arabic-English (ed. Huda al-Khattab; trans. Nasiruddin al-Khattab) (Riyadh - Jeddah: Maktaba Dar-us-Salam 2012) I.

42 That is why they soon became an effective tool for religious instruction, Günther, "The Poetics," 184, 190-191. 
Al-Qửān al-Karìm (Dimašq - Bayrūt: Al-Yamām li-ț-Ṭibāa wa-n-Nashr wa-t-Tawzì‘ 1404 AH/1983).

Al-Qurțubī, Abū 'Abd Allāh, Al-Ğamī' li-ahkām al-Qur'ān wa'l-mubayyin li-mā tadammanahu min as-sunna wa-'āy al-furqān (ed. 'Abd Allāh b. 'Abd al-Muhsin at-Turkī) (Bayrūt: Mu'assasat ar-Risāla 1427 AH/2006) XVII-XVIII.

Al-Qurțubī, Abū 'Abd Allāh, Al-Muhtaṣar aṣ-șahīh min at-taḍkira fī aḥwāl al-mawtā wa-l'āhira. An Authentic Selection from Imam Al-Qurtubi's at-Tadhkirah fī ahwālil-Mawtā wal-Äkhirah (trans. Reda Bedeir) (El-Mansoura: Dar al-Manarah 1425 AH/2004).

Șahịh al-Buhārī / The Translation of the Meanings of Sahīh Al-Bukhārī. Arabic-English (trans. Muhammad Muhsin Khan) (Riyadh: Maktaba Dar-us-Salam 1997) II, V.

Șaḥịh Muslim / English Translation of Sahīh Muslim. Arabic-English (ed. Hāfiz Abu Tāhir Zubair 'Ali Za'i; trans. Nasiruddin al-Khattab) (Riyadh - Jeddah: Maktaba Dar-us-Salam 2007) VI-VII.

Nasr, S.H. et al. (eds.), The Study Quran. A New Translation and Commentary (New York: HarperOne 2015).

Sunan Ibn Māğa / English Translation of Sunan Ibn Mājah. Arabic-English (ed. Hāfiz Abu Tāhir Zubair 'Ali Za’i; trans. Huda Khattab) (Riyadh - Jeddah: Maktaba Dar-us-Salam 2007) IV-V.

\section{Secondary literature}

Akar, S., “No', Said the Prophet. Socio-Rhetorical Analysis of a Hadith," Studia Orientalia Electronica 85 (2014) 93-114, https://journal.fi/store/article/view/44001 [access: May 2020].

Al-Ašqar 'Umar Sulayman 'Abd Allāh, 'Ālam al-malāika al-abrār, 3 ed. (Al-Kuwayt: Maktabat al-Falāḥ 1403 AH/1987).

Āšūr Muștafā, 'Ālam al-malāika: asrāruhu wa-ḩafāyāhu (Al-Qāhira: Maktabat al-Qurān [s.a.]). von Bothmer, H.-C.G. - Ohlig, K.-H. - Puin, G.-R., "Neue Wege der Koranforschung," Magazin Forschung 1 (1999) 33-46.

Brow, D.W., "Western Hadith Studies," The Wiley Blackwell Concise Companion to the Hadith (ed. D.W. Brown) (Hoboken, NJ: Wiley Blackwell 2020) 39-56.

Gaudefroy-Demombynes, M., Narodziny islamu (Warszawa: PIW 1988).

Günther, S., "The Poetics of Islamic Eschatology: Narrative, Personification, and Colors in Muslim Discourse," Roads to Paradise. Eschatology and Concepts of the Hereafter in Islam.

I. Foundations and Formation of a Tradition. Reflections on the Hereafter in the Quran and Islamic Religious Thought (ed. S. Günther - T. Lawson) (Leiden - Boston: Brill 2017) 181-216.

Ibn Manz̄ūr, Lisān al-Arab, http://arabiclexicon.hawramani.com/ibn-manzur-lisan-al-arab/ [access: May 2020].

John Paul II, Crossing the Threshold of Hope, 11 ed. (New York: Knopf 2005).

Juynboll, G.H.A., The Encyclopedia of Canonical Hadith (Leiden - Boston, MA: Brill 2009).

Kościelniak, K., Tematyczna konkordancja do Koranu (Kraków: Unum 2006).

Kościelniak, K., Tradycja muzutmańska na tle akulturacji chrześcijańsko-islamskiej od VII do $X$ wieku. Geneza, historia i znaczenie zapożyczeń nowotestamentowych w hadisach (Kraków: Unum 2001).

Lane, E.W., Arabic-English Lexicon (Vadus: Thesaurus Islamicus Foundation 2003) [CD-ROM]. 


\section{BOŻENA PROCHWICZ-STUDNICKA}

Macdonald, D.B., "Malāika. In the Kurān and Sunnī Islam," The Encyclopaedia of Islam. New Edition (Leiden: Brill 1991) VI, 216-219.

Macdonald, J., “The Twilight of the Death,” Islamic Studies 4/1 (1965) 55-102.

Nöldeke, Th. et al., The History of the Qur'ān (Leiden: Brill 2013).

O'Shaughnessy, Th., Muhammad's Thoughts on Death. A Thematic Study of the Quranic Data (Leiden: Brill 1969).

Pavlovitch, P., "Dating," The Wiley Blackwell Concise Companion to the Hadith (ed. D.W. Brown) (Hoboken, NJ: Wiley Blackwell 2020) 113-133.

Penrice, J., A Dictionary and Glossary of the Kör-ân (London: Curzon 1873).

Sadeghi, B. - Bergmann, U., "The Codex of a Companion of the Prophet and the Qurān of the Prophet," Arabica 57/4 (2010) 343-436.

Sadeghi, B. - Goudarzi, M., "Șană' I and the Origins of the Qurān," Der Islam 87/1-2 (2012) $1-129$.

Schoeler, G., "Recording," The Wiley Blackwell Concise Companion to the Hadith (ed. D.W. Brown) (Hoboken: Wiley Blackwell 2020) 91-112.

Sinai, N., The Quran. A Historical-Critical Introduction (Edinburgh: Edinburgh University Press 2017).

Smith, J.I. - Haddad, Y.Y., The Islamic Understanding of Death and Resurrection (Oxford: Oxford University Press 2002).

Wensinck, A.J., A Handbook of Early Muhammadan Tradition (Leiden: Brill 1927).

Wensinck, A.J., The Muslim Creed. Its Genesis and Historical Development, 3 ed. (London New York: Routledge 2008).

Wilson, P.L., Angels (New York: Pantheon 1980). 